\title{
РИТУАЛИ І ВЛАДА. ТРАДИЦІЇ СТРІЛЕЦЬКОГО ТОВАРИСТВА У ЛЬВОВІ КІНЩЯ ХІХ - ПОЧАТКУ ХХ СТОЛІТТЯ
}

Анотація: Мова у статті йде про одну з найбільш впливових організацій Львова - Стрілецьке товариство, та які ритуали і традиції використовувалися ї членами для обгрунтування свого впливу на міську політику. Члени Товариства часто ставали депутатами Ради міста, а також Президентами та віще-президентами Львова. Цю структуру звинуватили у тому, що вона фактично узурпувала владув вісті.

Стрілецьке товариства (або Стрільниия) мала довгу історію, яка сягала в часи розквіту Речі Посполитої. А це було важливо у період австрійської автономії (з 70-тих років XIX ст. до початку Першої світової війни), коли Рада міста Львова декларувала «відновлення та збереження польської культури на теренах колишньої Польщі». Таким чином Стрільниия із товариства озброєних міщан перетворилася на елітний клуб, який мав вирішальний вплив на місцеву політику.

Ключові слова: ритуали, маніфестащії, Стрілецьке товариство, Львів, еліта

Історія останньої третини XIX - початку XX століття - це період конституційних реформ в імперії Габсбургів. Внаслідок цих змін Рада міста Львова, як орган місцевого самоврядування, отримала реальні важелі впливу. А отже у Львові, як і скрізь а АвстроУгорщині, з'явилася місцева політика сучасного типу.

Про діяльність Ради міста Львова, її роль, структуру, функції грунтовно описано в праці Лукаша Сроки ${ }^{1}$ Автор зокрема говорить і про Стрілецьке товариство - як про неофіційну групу впливу всередині Ради. Про інший аспект даної статті, а саме - про культивування польського історичного міфу у Львові часів автономії, йдеться в працях істориків Харальда Біндера ${ }^{2}$, Патріс Домбровскі ${ }^{3}$, Маркіяна Прокоповича ${ }^{4}$, Остапа Середи ${ }^{5}$ й ін.

Попри те, що тема цікавить істориків, багато подій чи явищ досі навіть не описано. Адже це був час не лише активного політичного життя (коли з'являлися нові партії та рухи), але й

\footnotetext{
* Кісь Назар Данилович - кандидат історичних наук, науковий співробітник відділу нової історії України Інституту українознавства імені I. Крип'якевича НАН України (Львів, Україна); ORCID: https://orcid.org/0000-0003-4143-1862; e-mail: danylovych@gmail.com

${ }^{1}$ Sroka E. Rada Miejska we Lwowie w okresie autonomii galicyjskiej 1870-1914: studium o elicie władzy. Wydawnictwo Naukowe Uniwersytetu Pedagogicznego, Kraków, 2012. 565 s.

${ }^{2}$ Binder H. Making and Defending a Polish Town: «Lwow» (Lemberg), 1848-1914 // Austrian History Yearbook. 2000. Vol. 34. P. 57-81.

${ }^{3}$ Dabrowski P. Commemorations and the Shaping of Modern Poland. Bloomington: Indiana University Press, 2004. $312 \mathrm{p}$.

${ }^{4}$ Prokopovych $M$. Habsburg Lemberg: architecture, public space, and politics in the Galician capital, 1772-1914. Purdue University Press, West Lafayette, Indiana, 2009. 357 p.

${ }^{5}$ Середа О. Масові урочистості та міський публічний простір // Ісаєвич Я., Литвин М., Стеблій Ф. (ред.). Історія Львова. Т. 2. Львів, 2007. С. 301-317.
} 
активної фіксації того, що сталося (у мемуарах, документах і численних газетних виданнях). Існує величезна кількість матеріалів, які ще не опрацьовані.

у період автономії, тобто фактично з 1870-х рр., Рада міста Львова (як орган самоврядування) брала активну участь у різного роду патріотичних заходах. При чому самі міські депутати переважно і були ініціаторами ї проведення. В основному це були загальнопольські річниці чи ювілеї, як-от: Січневого чи Листопадового повстання, Конституції 3 травня тощо. А були і приклади власне локальних дат, присвячені подіям 3 минулого Львова, наприклад: річниця облоги Львова військами Богдана Хмельницького та святкування дати «першого заснування» Львівського університету королем Яном Казимиром.

Дуже популярними були ювілеї різноманітних товариств. Для цього у минулому шукали приклади, які б ілюстрували участь «міщан» чи «товариств» у загальнонаціональній історії. Святкували дати заснування цехів, організацій, добровільних пожежних дружин тощо. Серед цих товариств видатне місце займало Стрілецьке («куркове») товариство - так звана Стрільниця.

Отже, метою нашої публікації є розкрити як неофіційна (але всім відома та визнана) група впливу в Раді міста - Стрілецьке товариство («Стрільниця») репрезентувала себе, і як обгрунтовувала своє «право» впливати на політику. В згаданий період «Стрільниця» стала фактично «партією влади» у Львові. У цьому товаристві сформувався специфічний механізм персональних стосунків, де фігурували члени Ради міста та Президенти міста. Часто голова Товариства ставав Президентом. Тут збиралися впливові підприємці та представники ремісництва. При цьому середовище «Стрільниці» було доволі герметичним. I цей факт, між іншим, ставить під сумнів твердження про демократизацію політики у Львові часів автономії, яке ілюструється перемогами на виборах ремісників і підприємців ${ }^{6}$. Як влучно було написано у газеті «Діло» у 1907 р. $з$ приводу виборів Президента Львова, «так звана стрільниця - збагачені промисловці, що верховодять у міській раді» 7 .

Важливим для саморепрезентації «Стрільниці» було й те, що Стрілецьке товариство мало довгу історію. У період автономії (а це період «відродження» польського характеру міста) все, що пов'язувало із «старими добрими часами Речі Посполитої», ставало частиною національного наративу та бралося на озброєння польськими політиками. Так і Стрільниця 3 часом перетворилася на національну, а не міську організацію, члени якої підкреслювали зв'язок з іншими польськими стрілецькими товариствами ${ }^{8}$ Жодної практичної функції 3 «оборони Львова» товариство давно уже не виконувало. Це був елітний клуб, офіційною місією якого було «продовжувати традицію» - організовувати змагання на свято Божого Тіла, вибирати «куркового короля» та проводити паради.

Зважаючи на той факт, що члени «Стрільниці» нерідко ставали керівниками міста, не дивно, що на стрілецьких урочистостях часто були присутні маршалок Сейму, Президент міста Львова, майбутні та колишні Президенти, значна частина Ради міста, адже вони були членами Стрілецького товариства. А Рада міста Львова і тут відігравала провідну організаційну роль, виправдовуючи свій самоприсвоєний титул «найпатріотичнішого і найдемократичнішого осередку польського життя на теренах трьох частин розділеної Польщі».

\footnotetext{
${ }^{6}$ Sroka Ł. Rada Miejska we Lwowie... S. 230-231.

${ }^{7}$ Вибір президента міста Львова // Діло. 1907. 2 травня (Ч. 89). С. 3.

${ }^{8}$ Prokopovych M. Habsburg Lemberg... P. 208.
} 
Свято Божого Тіла. У XIX - першій половині XX ст. у Львові традиційно проводилися релігійні урочистості виразно «польського» та «руського» характеру. Головним «руським» святом був Йордан (Водосвяття) за юліанським календарем, який закінчував різдвяний цикл. У цей день на площі Ринок урочисто освячували воду в присутності тисяч вірян 9 . «Польським» святом можна вважати свято Божого Тіла, хоча коректніше говорити про цілу серію святкувань після Великодня за григоріанським календарем. Вони тривали під час Зелених Свят, у неділю після них і на свято Євхаристії (Божого Тіла). На свято Євхаристії навколо католицьких храмів звично проводять урочисті процесії зі Святими Дарами. У Львові в цей день (тобто протягом часу від Зелених Свят) відбувалися ще й заходи Стрілецького товариства: паради, салюти, масові гуляння, а також ритуал «переобрання куркового короля» - найкращого стрільця року.

До стрілецьких святкувань активно були залучені Рада міста (і Ратуша як місце проведення урочистостей) і римо-католицьке духовенство. Так, у 1911 р. в перший день Зелених Свят (який того року припав на 4 червня), зі звичною помпою та середньовічними атрибутами проводили «детронізацію куркового короля». Зранку члени Стрілецького товариства зібралися в Ратуші, обійшли навколо площі Ринок і вирушили до помешкання діючого «короля» (у даному випадку - на вулиці Коперника), щоб забрати в нього срібну булаву Товариства. Звідти, так само урочисто, через площу Галицьку, Бернардинську, вулицю Чарнецького та Куркову - до Стрільниці (будинку Товариства). Тоді, так само урочисто і з музикою, члени Товариства пішли до монастиря францисканців на месу, а потім знову повернулися до Стрільниці. Фактично, урочиста процесія за день пройшлася через усе середмістя.

У будинку Товариства на вулиці Стрілецькій, перед портретом короля Речі Посполитої Сигізмунда II Августа, «курковий король і обидва маршалки» склали свої регалії, колишній уже «король» отримав пам'ятний подарунок - золотого когутика, і відкрив змагання серед стрільців за звання нового «короля». Саме короля Сигізмунда Августа члени Товариства вважали засновником Стрілецького товариства, відповідно, історію організації виводили 3 часів, коли Польща ще не втратила державності. Фактично, члени Куркового товариства маніфестували, що бережуть давні, «доавстрійські» традиції, а Рада міста їм активно у цьому допомагає $\epsilon^{10}$.

Наступний тиждень був присвячений змаганням на звання нового «куркового короля», чия каденція тривала рік, до наступних Зелених свят. Стрільби розпочиналися у понеділок, а закінчувалися в неділю.

Після цього члени Товариства готувалися до урочистостей на день Божого Тіла. Того року він припав на четвер 15 червня 1911 р. Це було велике католицьке свято, яке масово відзначалося і на державному рівні. У Львові в традиційній процесії зі Святими Дарами навколо головного костелу міста - Латинської катедри, взяли участь представники вищого духовенства, намісник, маршалок Сейму, представники автономії, вище військове

\footnotetext{
${ }^{9}$ Колб Н. Громадські акції Греко-католицької церкви у Львові в 90-х роках XIX століття // Львів: місто суспільство - культура. 3б. наук праць за ред. О. Аркуші і М. Мудрого. Львів, 2007. Т. 6. [Вісник Львівського університету. Серія історична. Спеціальний випуск '2007]. С. 359-387.

${ }^{10}$ Detronizacja króla kurkowego // Kurier Lwowski. 1912. 28.05. Nr. 241. S. 4; Uroczystości strzeleckie // Kurjer Lwowski. 1911. 7.06. Nr. 256. S. 3; Boże Ciało // Kurier Lwowski. 1912. 7.06. Nr. 257. S. 4.
} 
командування тощо. I серед них - члени Куркового товариства у національних костюмах. Був також парад із залученням військових львівського гарнізону.

I в цей же день відбувалася «інтронізація» нового «куркового короля». Загалом, ритуал повторював процес «детронізація» попереднього: богослужіння, збори в Ратуші, урочистий похід через усе Середмістя (тепер уже до помешкання нового «короля»), знову похід на Стрільницю. Тут відбувалася процесія навколо самого будинку Стрільниці (як зі Святими Дарами навколо храму) та власне «інтронізація». Завершувалося все дійство «королівським бенкетом» і початком нових змагань, тепер уже не за звання, а за призи ${ }^{11}$.

Слід визнати, що члени Стрілецького товариства вдало використовували час. Адже і Зелені Свята, і день Божого Тіла - це традиційні католицькі свята, коли проводяться масові урочистості. I їх, певною мірою, вдалося зробити фоном для проведення ритуалів організації та патріотичних маніфестацій.

Річнищя 350-річчя Стрілещького товариства у Львові, яка проходила 18 жовтня 1896 р., $є$ ще однією ілюстрацією того, наскільки важливою була ця організація для Ради міста. I як патріотичні ритуали використовувалися для обгрунтування політики. По суті, це міг би бути звичайний ювілей, якби не роль Стрільниці у формуванні персонального складу львівської місцевої влади. І якби не історія Товариства, яка зв'язувала сучасність під владою Австрії зі «славним минулим Речі Посполитої».

Коли члени організації сформували колону для походу на урочисту месу, попереду цієї колони йшла міська капела «Гармонія», далі - «курковий король», яким тоді був віцепрезидент Львова Міхал Міхальський (він згодом став Президентом міста Львова). Опісля йшли другий віце-президент Станіслав Цюхцінський і Президент Львова Ґодзімір Малаховський (теж члени Стрілецького товариства). Потім ішли кількасот членів організації у національних костюмах, а за ними - офіційна репрезентація Ради міста.

Богослужіння у костелі францисканців відправляв вірменський архієпископ, відомий польський патріот Ісаак Ісакович у супроводі численного духовенства та міського музичного товариства «Лютня». Його промова, передбачувано, була присвячена ролі Товариства у збереженні традицій, патріотизму та католицизму. Подалыші урочистості відбувалися у будинку Стрільниці та в Ратуші. На Стрільниці розмістили меморіальну таблицю на честь ювілею, а ввечері провели бенкет. У Ратуші прочитали лекцію, присвячену історії Товариства. Такі лекції наприкінці XIX - на початку XX ст. стали традиційними та присвячувалися різним історичним подіям: Конституції 3 травня, Листопадовому та Січневому повстанням, заснуванню Львівського університету чи історії облоги Львова 1655 року.

Цікавим в ідеологічному плані був вечірній бенкет. Присутній на ньому маршалок Крайового сейму граф Станіслав Бадені говорив про важливість самоврядування для краю та міста (очевидно, у контексті збереження національних традицій). А також про католицизм, жертовність і любов до батьківщини. Гостям зачитали вітальні телеграми від стрілецьких товариств Кракова та Познані (які у цей час теж були радше національними, а не міськими організаціями). Такі стосунки зі структурами «усіх частин Польщі» були дуже важливими для політиків Львова періоду автономії.

\footnotetext{
${ }^{11}$ Strzelanie królewskie // Kurier Lwowski. 1911. 13.06. Nr. 267. S. 4; [Uroczystość Bożego Ciała // Kurier Lwowski. 1911. 16.06. Nr. 271. S. 3; Uroczystość strzeleckie // Kurier Lwowski. 1911. 16.06. Nr. 271. S. 3; Uroczystość Bożego Ciała // Gazeta Lwowska. 1911. 17.06. Nr. 136. S. 3.
} 
Про статус Товариства свідчить і той факт, що протягом бенкету гостей розважав оркестр 30 полку піхоти ${ }^{12}$.

Треба розуміти, що всі ритуали, описані вище, обгрунтовувалися потребою засвідчити розвиток «польського стану посідання в краї». Австрійська частина розділеної Речі Посполитої була найбільш демократичною, що з одного боку давало місцевим польським елітам більші можливості для розвитку національного проекту, а з іншого - покладала на них більше відповідальності. Тому члени Стрілецького товариства наголошували на тому, що «в теперішній час» (це був прозорий натяк на втрату незалежності) дуже важливо пам'ятати про свою історію. Звідси - і регулярне звертання до постаті короля Сигізмунда Августа, i традиційні польські національні костюми «кунтуші», і нав’язування до «загально польських звичаїв» - стрілецьких змагань під час Зелених Свят, які тоді ж відбувалися у Кракові, Познані й інших польських містах.

Але банальним «пригадуванням історії» та «відновленням християнських і національних традицій» справа не обмежилася. Наприклад, визнаючи німецькі впливи під час утворення стрілецьких товариств у середньовічних містах, організатори та ідеологи зверталися до давнішої історії, де ніби-то були «передумови» до їх діяльності. А також підкреслювали вплив польських королів, які надавали цим структурам привілеї ${ }^{13}$.

Характерно, що українська преса подібні згадані у статті святкування повністю ігнорувала. Максимум, що можна зустріти в українських газетах - це нарікання на утвердження «польського стану посідання» в місті, столиці «Галицької Русі», де українці вважали поляків колонізаторами.

Iнші урочистості, які проходили у Львові, теж не обходилися без активної участі Товариства. Наприклад, цісар Франц Йосиф, відвідуючи Львів, неодноразово бував на Стрільниці і навіть здобув титул найвлучнішого стрільця ${ }^{14}$. Звичайно, до умов проведення цього «конкурсу» може бути багато питань, але безумовним є те, що Стрілецьке товариство вдало скористалося візитами імператора для утвердження свого іміджу провідної міської та патріотичної організації.

Описуваний візит, який відбувся під час першого приїзду Франца Йосифа до Львова у 1851 р., анонсували як відвідини «давньої інституції нашої столиці, яку до цього відвідували Франц I та архикнязь Франц Карл». Тут для молодого імператора спорудили тріумфальну арку, показали мішені, по яких стріляли імператор Франц I та батько Франца Йосифа Франц Карл, хоругву, яку подарувала цісарева Марія Анна у 1844 р. й інші реліквії. Серед них, зокрема, золоту фігурку півня - подарунок короля Сигізмунда Августа. Таким чином, Товариство показало себе як давню інституцію, лояльну до влади. Хоч і з історією, значно довшою за австрійське панування.

Іншим вдалим політичним ходом було те, що стрілецькі розваги цього разу мали на меті зібрати кошти для товариства інвалідів. А Франц Йосиф, як відомо, був видатним

\footnotetext{
${ }^{12}$ Towarzystwo strzeleckie // Gazeta Lwowska. 1896. 20.10. Nr. 240. S. 4; 350 letni jubileusz istnienia lwowskiego Towarzystwa strzeleckiego // Kurjer Lwowski. 1896. 18.10. Nr. 290. S. 3.

${ }^{13}$ Srtrzeleckie święto // Gazeta Lwowska. 1896. 20.10. Nr. 240. S. 4-5; Uroczystość 350-letniego istnienia Tow. strzeleckiego // Kurjer Lwowski. Dodatek do nr. 292.1896. 19.10. S. 2.

${ }^{14}$ Кiсь Н. Цісар прибуває! Візити Франца Йосифа до Львова. Центр міської історії. Інтерактивний Львів. 2020. URL: https://lia.lvivcenter.org/uk/themes/kaiser-visits/
} 
меценатом і благодійником. Цісар влучив у мішень 3 першого разу, про що місто відразу сповістили гарматні залпи, додав до призових коштів (які йшли на благодійність) ще й свої власні та розписався у пам'ятній книзі ${ }^{15}$.

Відвідини цісарем Стрільниці повторилися ще тричі: у 1855, 1880 і 1894 рp. Імператор стріляв по мішенях, розписувався у книзі почесних гостей. Золоте перо, яким він писав, стало частиною колекції реліквій Товариства. Як і мішень, пробита ним у 1855 році ${ }^{16}$.

Члени товариства у національних костюмах і зі штандартом організації брали участь практично в усіх ювілейних заходах, присвячених національним польським ювілеям: Конституції 3 травня, річниці Люблінської унії, Січневого та Листопадового повстань, вшануванні страт повстанців Вішньовського і Капусцінського та багатьох інших заходах.

Саме приміщення Стрільниці та парк навколо нього часто використовувалося для бенкетів, фестин, урочистих зустрічей. Так було, наприклад, під час ще одного історичного ювілею - «250-ліття першого заснування Львівського університету Яном Казимиром». Тоді студенти і професори Львівського університету, проводячи ювілейні заходи (а сам ювілей організовувався як аргумент проти заснування у Львові українського університету), влаштували на Стрільниці вечірку.

Хоча до того, як польсько-українські відносини досягнули піку напруженості наприкінці XIX - на початку XX ст., Стрільниця використовувалася й українщями. Наприклад, у 1883 р. там розважалися учасники «Другого всенародного українського віча», руський студентський хор організував тут концерт пам'яті Маркіяна Шашкевича.

Отже, ритуали пов'язані зі Стрільницею, були вдало вплетені у традиційний католицький календар. А оскільки Рада міста та Стрільниця, якщо йдеться про персональний склад, дуже часто були тотожними, то весь патріотичний образ, історія, тяглість від Речі Посполитої і давньої героїчної історії переходив від Стрілецького товариства до міської ради. А Рада міста, як орган самоврядування, уже займалася «відродженням Польщі» в умовах, наданих австрійською конституцією.

Діяльність Стрільниці давала місцевим політикам і Раді міста одразу декілька переваг. По-перше, вони могли домовлятися про владу в своєму тісному колі, це очевидно. Але, подруге, і в плані ідеології Стрілецьке товариство допомагало триматися на плаву. Адже важливо було засвідчити свою «присутність у місті», а також цю присутність обгрунтувати. I тут на допомогу керівникам Ради міста приходила історія Стрільниці. Для початку - це «славне минуле львівського міщанства». Коли бралися події часів Речі Посполитої, які обгрунтовували позицію сучасної Ради міста, орієнтованої на «відродження Вітчизни». А далі - це коли відзначалися успіхи місцевого самоврядування чи просто самоорганізації протягом уже австрійського періоду. Тобто у цьому випадку використовувалася як «доавстрійська», про «старі-добрі часи», історія Речі Посполитої. Так і нещодавнє минуле, здатне проілюструвати спроможність поляків до управління (а отже - i державності) тут і тепер.

\footnotetext{
${ }^{15}$ Przegląd. Gazeta Lwowska. 1851. 18.10. № 240. S. 1-2.

${ }^{16}$ Кісь Н. Цісар прибуває! Візити Франца Йосифа...
} 


\section{Rituals and Power.}

\section{Traditions of the Riflemen's Society in Lviv at the end of the XIX - early XX century}

Annotation: The article is about one of the most influential organizations in Lviv - the Riflemen's Society. And about the rituals and traditions used by its members to justify their influence on urban policy. Members of the Society often became deputies of the City Council, as well as Presidents and Vice-Presidents of Lviv. This structure was accused of actually usurping power in the city.

The Riflemen's Society had a long history, dating back to the heyday of the Commonwealth. This fact was important during the period of Austrian autonomy (from the 1870s to the beginning of the First World War), when the Lviv City Council declared «the restoration and preservation of Polish culture in the territory of former Poland». Thus, the Riflemen's Society from the society of armed citizens of the city became an elite club that had a decisive influence on local politics.

The article considers several examples that give an understanding of the rituals and traditions of Society. And also it's place in the public life of Lviv. It describes, in particular, the traditional annual «election of the King of Riflemen», when members of the organization gathered in the Town Hall, marched through the city and organized competitions. And also the celebration of the $350^{\text {th }}$ anniversary of the Society. As well as the role of the Riflemen's Society during the emperor's visits to Lviv or during Polish patriotic anniversaries etc.

Since the City Council and Rifleman Society, when it comes to personnel, were very often identical, the whole patriotic image, history, longevity from the Commonwealth and ancient heroic history passed from the Rifleman's Society to the city council. And the City Council was already engaged in the «revival of Poland» under the conditions provided by the Austrian constitution.

The Riflemen's Society gave local politicians and the City Council several advantages at once. First, they could resolve their issues outside of formal procedures. Secondly, the history of the Rifleman's Society was an argument in discussions about the history of the city and the presence of Poles in it. The very existence of this society was proof of the «revival of Poland» in Lviv. Third, the Society's success was proof of the success of a «Polish political project» in Galicia that was able to govern society.

Keywords: rituals, manifestations, Rifle Society, Lviv, elite 